\title{
Hubungan antara School Well-Being dengan Rumination
}

\author{
Sandi Kartasasmita \\ Fakultas Psikologi, Universitas Tarumanagara \\ Email : Sandik@f.psi.untar.ac.id
}

\begin{abstract}
ABSTRAK
Tujuan penelitian ini adalah untuk mengetahui hubungan antara School Well-being dengan rumination. Teori School Well-being dikemukakan oleh Konu dan Rimpela dan teori rumination dikemukakan oleh Susan NolenHoeksema. School well-being adalah penilaian individu berkaitan dengan keadaan lingkungan sekolah tempat belajar, sedangkan rumination adalah pola pikir yang berulang yang berakar pada mood negatif (seperti kesedihan) dan tidak memotivasi seseorang untuk menyusun rencana untuk menghilangkan pemikiran tersebut. Penelitian ini melibatkan 126 responden. Penelitian ini menggunakan metode kuantitatif. Hasil penelitian menunjukan bahwa tidak terdapat hubungan $(r=-0.016, p>0.05)$. Namun, dari hasil penelitian pada dimensi ruminasi indikator depresi, terdapat hubungan dengan School Well-Being $(r=-0.191, p<0.05)$. Demikian pula dengan perhitungan untuk indikator Brooding dalam ruminasi dengan indikator health dalam School Well-Being terdapat hubungan yang signifikan $(r=0.211, p<0.05)$.
\end{abstract}

Kata kunci: School Well-being, Rumination, Depresi, Brooding, Health

\section{PENDAHULUAN}

Dalam dunia pendidikan, prestasi akademis menjadi salah satu hal penting yang perlu menjadi perhatian para siswa. Tuntutan akan prestasi akademis terlihat dari iklan lowongan pekerjaan yang memberikan syarat minimal IPK (Indeks Prestasi Kumulatif) saat mengajukan lamaran. Kondisi tersebut menjadi lebih menekan dan membuat stress dibandingkan dengan saat masih di SMA (Mudhovozi, 2012; Salami, 2011). Hal ini tidak dapat dihindari karena memang semakin tinggi tingkat pendidikan, maka akan semakin besar pula tekanan yang akan dihadapi oleh siswa. Semakin tinggi tekanan tersebut dapat membuat siswa menjadi merasa tidak puas dan tidak bahagia (Andiani \& Wijaya E, 2010). Siswa yang bahagia biasanya akan melakukan kegiatan akademik lebih baik daripada yang tidak bahagia. Siswa yang merasa puas dengan tempatnya belajar, maka akan memperlihatkan prestasi akademik yang lebih baik daripada yang tidak puas. Selain itu, siswa yang tidak puas terhadap tempatnya belajar akan memiliki kecenderungan berprilaku buruk, kurang berprestasi bahkan sampai Drop out.

Konu dan Rimpela (2002) mengungkapkan bahwa apabila situasi tempat individu belajar dianggap sehat, maka akan memberikan perasaan senang dan membentuk sikap dan penilaian yang positif dari siswa. Perasaan senang dan puas akan menurunkan tingkat stress pada siswa dan akhirnya akan meningkatkan achievement. Achievement sendiri dapat dipengaruhi rumination (ruminasi). Individu yang melakukan ruminansi memiliki risiko tinggi dalam penurunan performa dalam bidang akademik (Gouw, E \& Kartasasmita, S, 2015). Hal ini disebabkan karena dampak dari melakukan ruminansi adalah menjadi pemicu depresi, kemampuan penyelesaian masalah yang rendah, berkurangnya dukungan sosial, menurunnya kemampuan kognitif, dan menghambat perilaku yang produktif. Penelitian ini bertujuan untuk mengetahui hubungan school well-being dengan ruminasi pada mahasiswa.

\section{Tinjauan Teoretis}

School Well-being adalah keadaan yang memungkinkan seseorang untuk memuaskan kebutuhan-kebutuhan dasarnya, baik kebutuhan material maupun non material. Pemahaman ini dikembangkan oleh Konu dan Rimpela berdasarkan teori well being dari Alldart (Konu \& Rimpela, 2002). Dua kebutuhan tersebut oleh Konu dan Rimpela (2002) dibagi menjadi Having, Loving dan Being. Lebih lanjut lagi, berdasarkan penelitian yang dilakukan dan kajian-kajian 
literatur, baik secara sosiologis, pendidikan, psikologis dan kesehatan, maka Konu dan Rimpela akhirnya merumuskan konsep ini lebih menyeluruh. Perumusan tersebut menghasilkan dimensi health dipisahkan dengan dimensi having dan menjadi satu dimensi tersendiri, sehingga pada akhirnya dimensi dari school well-being adalah Having, Loving, Being dan Health. School wellbeing sendiri adalah satu kondisi atau keadaan saat seseorang dapat memuaskan kebutuhankebutuhan dasarnya di lingkungan pendidikan, dalam hal ini sekolah atau perguruan tinggi. Hal ini berkaitan dengan kegiatan belajar dan mengajar. Hal ini menandakan bahwa school wellbeing merupakan penilaian individu terhadap diri sendiri yang berkaitan dengan keadaan lingkungan sekolah atau perguruan tinggi sehingga dapat memuaskan kebutuhan-kebutuhan dasarnya.

Menurut Konu dan Rimpela (2002), pada dimensi pertata, yaitu Having, merupakan kondisi sekolah. Kondisi tempat belajar meliputi lingkungan di dalam dan disekitar sekolah. Kondisi disekitar sekolah diharapkan merupakan tempat yang nyaman untuk belajar, bebas dari kebisingan, ventilasi yang baik, termasuk juga kurikulum, ukuran kelompok, jadwal pelajaran dan hukuman serta peraturan sekolah. Aspek berikutnya meliputi pelayanan siswa, seperti ada atau tidaknya kantin yang dirasakan nyaman oleh siswa, perpustakaan yang dapat menunjang proses belajar, pelayanan kesehatan dan konseling di sekolah. Dimensi kedua adalah Loving adalah hubungan sosial. Hal ini berkaitan dengan hubungan siswa dengan lingkungannya, termasuk pembelajaran dalam lingkungan sosialnya, hubungan siswa dengan siswa lainnya, dinamika kelompok yang terjadi dan juga hubungan antara lingkungan rumah dengan sekolah. Dimensi ketiga, yaitu Being merupakan sarana untuk pemenuhan diri. Hal ini untuk melihat adanya kemungkinan seorang siswa dapat belajar sesuai dengan minat, kemampuan dan kebiasaan yang ada pada siswa tersebut. Pada saat yang bersamaan pula, menerima umpan balik dan juga dorongan untuk berprestasi. Bagaimana siswa dalam pengambilan keputusan yang dapat memengaruhi kehidupan sekolah. Jumlah karya yang diterima oleh seorang siswa berkaitan dengan sarana pemenuhan diri. Dimensi keempat, yaitu health. Kondisi ini berkaitan dengan ketiadaan penyakit yang muncul karena dampak dari proses belajar.

Ruminansi adalah pola berpikir mengenai suatu hal secara berulang-ulang; terlalu mengkhawatirkan masa lalu dan masa depan; atau terus terjaga sepanjang malam memikirkan hal yang sama (Kumar, 2009). Ruminansi menurut Nolen-Hoeksema (dikutip dalam Papageorgiou \& Wells, 2004) merupakan pemikiran yang repetitif dan pasif yang berfokus terhadap perasaan sedih atau depresi dari diri sendiri. Menurut Nolen-Hoeksema, Wisco, dan Lyubomirsky (2008) ruminansi adalah perhatian atau atensi yang terfokus secara kompulsif pada suatu hal (baik hal itu sendiri, penyebab hal tersebut, dan akibat dari hal tersebut). Sekilas ruminansi terlihat serupa dengan perasaan khawatir, tetapi sebenarnya kedua hal tersebut berbeda (Nolen-Hoeksema, Wisco, \& Lyubomirsky, 2008).

Perbedaan tersebut terdapat pada ruminansi berfokus pada perasaan negatif dari suatu pengalaman yang tidak menyenangkan di masa lalu, sedangkan khawatir umumnya berfokus pada antisipasi atas hal-hal buruk di masa depan (Nolen-Hoeksema, Wisco, \& Lyubomirsky, 2008). Menurut Rippere (dalam Papageorgiou \& Wells, 2004) ruminansi adalah pikiran yang menetap, sulit dihilangkan, terus berputar-putar dan bersifat depresif; ruminansi merupakan hal yang umum terjadi sebagai respon atas mood negatif. Menurut Treynor, Gonzales, dan NolenHoeksema (dalam Kumar, 2009) ruminansi terbagi atas dua yaitu reflective pondering (refleksi) dan brooding (tenggelam dalam pikiran-pikiran negatif). Brooding merupakan bentuk ruminansi yang tidak membangun (unconstructive rumination) (Kumar, 2009). Seseorang yang menggunakan pola berpikir ruminansi tidak akan mengambil langkah aktif untuk memecahkan 
masalah yang dihadapinya, melainkan terus terikat pada masalah dan perasaan mereka (NolenHoeksema, Wisco, \& Lybomirsky, 2008). Wells dan Matthews (dikutip dalam Papageorgiou \& Wells, 2004) menyatakan seseorang rentan melakukan ruminansi apabila seseorang memiliki kepercayaan metakognitif secara positif dan negatif mengenai ruminansi.

Maksud dari kepercayaan metakognitif positif mengenai ruminansi adalah ruminansi digunakan sebagai strategi coping seperti seseorang melakukan ruminansi untuk memahami apa penyebab suatu hal terjadi pada diri seseorang (Papageorgiou \& Wells, 2004). Sedangkan kepercayaan metakognitif negatif dari ruminansi adalah ruminansi dipandang sebagai hal yang berbahaya, tidak mampu dikontrol, dan memiliki efek negatif bagi kehidupan sosialnya (Papageorgiou \& Wells, 2004). Contoh dari kepercayaan metakognitif positif mengenai ruminansi "saya perlu melakukan ruminansi untuk mengetahui apa yang menjadi penyebab depresi saya". Sedangkan contoh kepercayaan metakognitif negatif dari ruminansi adalah "ruminansi membuat saya memiliki kemungkinan untuk melakukan hal-hal yang membahayakan diri saya" dan "orang lain akan menolak saya apabila saya terus melakukan ruminansi". Ruminansi umumnya menyita sebagian besar waktu manusia ketika dilakukan (Kumar, 2009).

\section{METODE PENELITIAN}

Subyek penelitian adalah mahasiswa. Tidak dibatasi oleh jenis kelamin, Fakultas, RAS maupun Agama. Subyek berjumlah 126 orang yang berasal dari berbagai Perguruan Tinggi Negeri maupun Swasta yang ada di Indonesia. Teknik pengambilan data adalah systematic random sampling. Systematic random sampling merupakan tipe sampling probabilitas dengan seluruh anggota populasi (dalam hal ini yang dapat mengakses internet maupun media sosial) memiliki kesempatan dan peluang yang sama untuk menjadi sampel dan menggunakan informasi lengkap mengenai populasi yang akan digunakan. Keuntungan dari systematic random sampling adalah (a) salah satu metode simpel untuk menentukan sampel yang akan digunakan, (b) menekan biaya penelitian, (c) hasil data yang didapat dapat digunakan untuk tujuan inferensial, (d) sampel yang didapat bersifat menyeluruh dan dapat mewakili seluruh populasi, dan (e) pengolahan data sampel dapat digunakan untuk menarik kesimpulan dan generalisasi (Singh, 2006). Pengumpulan data dilakukan dengan penyebaran kuisioner secara online. Definisi operasional ruminansi. Ruminansi adalah pola pikir yang berulang yang berakar pada mood negatif (seperti kesedihan) dan tidak memotivasi seseorang untuk menyusun rencana untuk menghilangkan pemikiran tersebut. Dimensi ruminansi terdiri atas brooding (tenggelam dalam pemikiran negatif), reflection (refleksi), dan depressive-related (berkaitan dengan gejala depresi). Peneliti mengadaptasi kuisioner mengenai ruminansi yang bernama Ruminative Response Style (RRS). Nilai alpha-cronbach untuk dimensi brooding adalah 0,608. Hasil alpha-cronbach untuk dimensi brooding dinyatakan telah memenuhi syarat $(0,608>0,6)$. Contoh butir, "Saya selalu berpikir berulang kali apa yang menyebabkan saya mengalami masalah ini”. Skor alphacronbach untuk dimensi depressive-related sebesar 0,827. Hal ini menunjukkan bahwa item kuisioner ruminansi untuk dimensi depressive-related sudah baik $(0,827>0,6)$. Contoh butir " Saya merasa kesepian". Nilai alpha-cronbach untuk dimensi reflection adalah 0,606. Hasil alpha-cronbach untuk dimensi reflection juga dinyatakan telah baik $(0,606>0,6)$ dengan contoh butir "Saya suka mengingat setiap hal yang terjadi pada masa lalu secara berulang-ulang". Alat tes dibuat berdasarkan skala Likert.

Untuk alat ukur school well-being, peneliti menggunakan alat ukur yang dibuat Konu dan Rimpela yang telah diadaptasi oleh Andiani dan Wijaya, E (2015). Alat ukur ini terdiri dari empat dimensi, yaitu Habing, Loving, Being dan Health. Untuk dimensi Having, adalah dimensi yang mewakili kondisi perguruan tinggi. Nilai alfa-cronbach dari dimensi ini adalah 
$(0,749>0,6)$. Contoh butir "terdapat fasilitas kesehatan yang memadai dan berguna di kampus saya”. Dimensi kedua adalah Loving. Dimensi ini mewakili hubungan sosial siswa dengan lingkungannya, termasuk pembelajaran dan lingkungan sosial. Nilai alfa-cronbach dari dimensi ini adalah $(0,672>0,6)$. Contoh butir "saya mempunyai banyak teman di kampus". Dimensi ketiga adalah Being. Dimensi ini dianggap sebagai kemungkinan yang dimiliki siswa untuk mau belajar dengan minat, kemampuan dan kebiasaan dirinya. Nilai alfa-cronbach dari dimensi ini adalah $(0,738>0,6)$. Contoh butir "Pembimbing Akademik (PA) saya cukup memberikan perhatian kepada saya". Dimensi keempat dari alat ukur ini adalah Health atau kondisi kesehatan yang dapat juga didefinisikan sebagai ketiadaan penyakit atau kondisi kesehatan siswa melalui gejala penyakit maupun penyakit yang dideritanya. Nilai alfa-cronbach dari dimensi ini adalah $(0,637>0,6)$ dengan contoh butir "ketika dihadapkan dengan tumpukan tugas, saya dapat tidur dengan nyenyak".

\section{HASIL DAN PEMBAHASAN}

Dari 126 responden yang mengisi, maka didapatkan data bahwa 26 orang adalah laki-laki dan 100 orang adalah perempuan. 89\% responden adalah mahasiswa Psikologi, 1\% Teknik, 2\% TI, $1 \%$ Komunikasi, 3\% Ekonomi, 2\% kedokteran dan 2\% lain-lain.

Berdasarkan hasil olah data, ditemukan bahwa tidak terdapat hubungan yang signifikant antara School Well-Being dengan Ruminasi ( $\mathrm{r}=-0.016, \mathrm{p}>0.05)$. Namun, dari hasil penelitian pada dimensi ruminasi indikator depresi, terdapat hubungan dengan School Well-Being ( $\mathrm{r}=-0.191$, $\mathrm{p}<0.05)$. Demikian pula dengan perhitungan untuk indikator Brooding dalam ruminasi dengan indikator health dalam School Well-Being terdapat hubungan yang signifikan $(\mathrm{r}=0.211$, $\mathrm{p}<0.05)$.

Hal ini menunjukan bahwa hubungan antara school well-being dengan ruminasi walaupun tidak secara tegas berhubungan namun, memiliki kecenderungan ada keterkaitan. Hubungan yang negatif signifikan kemungkinan dapat terjadi karena jumlah responden yang minim.

Untuk indikator depresi yang berkaitan dengan dimensi school well-being, hal ini menandakan bahwa siswa dapat menjadi depresi saat mempersepsikan tempatnya belajar tidak mendukung kenyamanannya. Kondisi lingkungan tempat belajar ternyata memberikan peran yang cukup signifikan terhadap munculnya gangguan depresi. Hal ini memang telah diperkirakan oleh peneliti. Peneliti memiliki hipotesa bahwa lingkungan dapat memengaruhi kesehatan mental seseorang, dalam penelitian ini adalah siswa. Menarik lagi saat membahas hubungan antara brooding dengan health. Hal ini dapat terjadi karena individu yang lebih banyak memikirkan segala sesuatu dari sudut pandang negatif terus menerus dan tanpa disadari otomatis memiliki pola pikir negatif (Negative Automatic Thoughts $=N A T$ ) mengenai segala sesuatu akan memiliki kecenderungan untuk melihat unsur kesehatan sebagai hal yang penting. Ketiadaan unsur kesehatan dari sekolah tempat individu tersebut belajar akan memberikan pemikiran bahwa sekolah tidak menganggap penting kesehatan dan itu menjadi penganggu pikiran serta kesehatan mental.

\section{KESIMPULAN}

Berdasarkan hasil olah data dapat disimpulkan bahwa terdapat kecenderungan adanya keterkaitan antara ruminasi dengan school well-being. Saat individu memiliki pola ruminasi dalam cara berpikirnya, maka pengaruh lingkungan akan sangat mudah menjadi pencetus munculnya perasaan-perasaan yang tidak nyaman ataupun pikiran-pikiran yang negatif. Demikian pula sebaliknya, persepsi individu mengenai tempatnya belajar yang tidak nyaman dan 
menyenangkan kemungkinan akan memengaruhi pola pikirnya dan dapat menjadi ruminasi. Selain itu, pola coping terhadap satu kondisi juga menjadi perlu diperhatikan.

\section{REFERENSI}

Andiani \& Wijaya. E (2016). Hubungan School Well-being dan kecerdasan emosi dengan penyesuaian diri mahasiswa perantau tingkat pertama. Skripsi. Jakarta: Univeritas Tarumanagara

Gouw,E \& Kartasasmita, S. (2015). Pengaruh Ruminasi terhadap academic achievement pada mahasiswa tingkat sarjana. Skripsi. Jakarta: Universitas Tarumanagara

Kumar, S. M. (2009). The mindful path through worrying and rumination: Letting go anxious and depressive thoughts. Oakland, CA: New Harbinger Publication. Diunduh dari http://chomikuj.pl/stooges/music/coil/Nowy+folder/1.4+The+Relationship+between+Mind fulness+and+Uncontrollability+ruminative+thinking, 1051287012.pdf.

Konu, A., \& Rimpela, M. (2002). Well-being in School: A conceptual model. Health Promotion International, 17(1), 79-87.

Mudhovozi, P. (2012). Social and academic adjustment of first year university students. Journal Social Science, 33(2), 251-259.

Nolen-Hoeksema, S., Wisco, B. E., \& Lyubomirsky, S. (2008). Rethinking Rumination. Perspective on Psychological Science, 3(5), 400-424. Diunduh dari http://drsonja.net/wpcontent/themes/drsonja/papers/NWL2008.pdf.

Papageorgiou, C. \& Wells, A. (2004). Depressive rumination: Nature, theory, and treatment. West Sussex: John Wiley \& Sons, Ltd.

Salami, S.O (2011). Psychosocial predictors of adjustment among first year college of education students. Academic Journal, 8(2), 239-248.

Singh, Y.K. (2006). Fundamental of research methodology and statistics. New Delhi: New Age International Publishers. 